\title{
GLUT expression and 18F-FDG uptake in breast cancer cell lines
}

\author{
Ana M Abrantes ${ }^{1,2 *}$, Mónica Martins ${ }^{1,3,4}$, Ana C Gonçalves ${ }^{5,2}$, Maria C Rodrigues ${ }^{6}$, Ana C Mamede ${ }^{1}$, \\ Sónia D Tavares ${ }^{1}$, José M Lima ${ }^{3}$, Adriano Rodrigues ${ }^{6}$, Ana B Sarmento-Ribeiro ${ }^{5,2}$, Maria F Botelho ${ }^{1,2,6}$ \\ From 16th International Charles Heidelberger Symposium on Cancer Research \\ Coimbra, Portugal. 26-28 September 2010
}

Positron emission tomography (PET) using the radiolabeled glucose analogue 18F-FDG allows uncovering glycolysis processes within cancer cells and reveals high value in diagnosis, staging, relapse and therapeutic response evaluation in several malignancies. Breast cancer presents considerable variability when it comes to 18F-FDG uptake, which results in different sensitivity and specificity values related to this technique. 18F-FDG enters the cells through glucose transporters (GLUTs). Therefore, this study aims to determine the pattern of 18F-FDG uptake in various breast cancer cell lines with different hormonal and HER2 receptor's expressions, and to set a correlation with the expression of GLUT's 1 and 3.

The studies were performed in three different human breast cancer cell lines, MCF-7, HCC1806 and HCC1954. MCF-7 express estrogen and progesterone receptors (ER and PR), HCC1806 cells are triple negative and HCC1954 are negative for hormonal receptors, but overexpress HER2/neu. GLUT-1 and GLUT-3 expressions were assessed by flow cytometry.

Our results show that, besides HCC1806 and HCC1954 cells present higher GLUT-1 and GLUT-3 levels than MCF-7, we observe a higher 18F-FDG uptake in HCC1954 cells. In fact, HCC1806 cells show the lower 18F-FDG uptake comparing with other cell lines.

These results suggest that despite the dependability of GLUT-1 and GLUT-3 isoforms' overexpression for 18FFDG uptake, these receptors do not seem to be the unique responsible. Considering the absence of correlation between GLUT's expression and 18F-FDG uptake,

\footnotetext{
* Correspondence: mabrantes@ibili.uc.pt

${ }^{1}$ Biophysics/ Biomathematics Institute, IBILI - Faculty of Medicine, University of Coimbra, Coimbra, Portugal

Full list of author information is available at the end of the article
}

ER, PR and principally HER $2 /$ neu gains an apparent relevance in this process.

\section{Author details}

'Biophysics/ Biomathematics Institute, IBILI - Faculty of Medicine, University of Coimbra, Coimbra, Portugal. ${ }^{2}$ Centre for Investigation on Environment, Genetics and Oncobiology (CIMAGO), Faculty of Medicine, University of Coimbra, Coimbra, Portugal. ${ }^{3}$ Nuclear Medicine Department, Coimbra University Hospital, Coimbra, Portugal. ${ }^{4}$ Ceramics and Glass Engineering Department, University of Aveiro, Aveiro, Portugal. ${ }^{5}$ Biochemistry Department, Faculty of Medicine, University of Coimbra, Coimbra, Portugal. ${ }^{6}$ Institute of Nuclear Sciences Applied to Health (ICNAS), University of Coimbra, Coimbra, Portugal.

Published: 24 September 2010

doi:

Cite this article as: Abrantes et al:: GLUT expression and 18F-FDG uptake in breast cancer cell lines. BMC Proceedings 2010 4(Suppl 2):P21.

Submit your next manuscript to BioMed Central and take full advantage of:

- Convenient online submission

- Thorough peer review

- No space constraints or color figure charges

- Immediate publication on acceptance

- Inclusion in PubMed, CAS, Scopus and Google Scholar

- Research which is freely available for redistribution 